\title{
NSF urged to raise environmental efforts ...
}

[WASHINGTON] The US National Science Foundation (NSF) should increase its annual spending on environmental research from $\$ 600$ million this year to $\$ 1.6$ billion in five years' time. So concludes an interim report that was approved last week by the foundation's governing body, the National Science Board (NSB).

An NSB panel concluded that the foundation's support for basic research into environmental questions "represents only about one-third of the resources necessary" in view of "the overwhelming importance and exciting opportunities for progress in the environmental arena". The panel was chaired by Jane Lubchenco, a marine biologist at Oregon State University.

If implemented, the call for extra money would radically reorientate the NSF's $\$ 2.5$ billion university research portfolio. The report is the NSB's main response to an instruction in 1997 from the Congress that the foundation should put together a plan to establish and run a National Institute for the Environment (NIE).

But the report rejects the idea of a separate NIE or an environmental directorate within the foundation. It calls instead for a "highvisibility, NSF-wide organizational focal

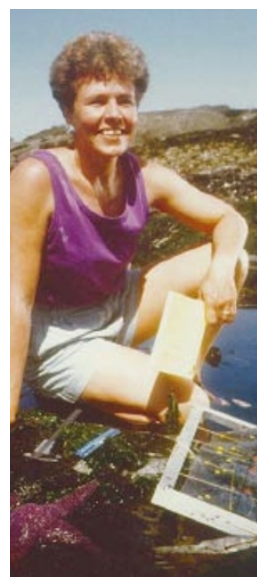

point" for environmental research. "A new directorate is not necessary," says Lubchenco.

This finding disappoints advocates of an NIE, who believe that the NSF will be unable to support interdisciplinary environmental work unless it augments its structure of discipline-specific directorates and divisions.

Lubchenco: 'no need "It's time for a major for a new directorate'. increased effort in environmental science at NSF," says Lubchenco. "An expanded effort is necessary, possible, and will be very exciting." Lubchenco adds that the foundation "will need a new focus on interdisciplinary research".

Eamon Kelly, an economist at Tulane University in Louisiana and NSB's chair, says the extra money is "a very conservative estimate" of what is needed. He adds that congressmen of various political perspectives want to see

\section{. as panel backs the return of the 'green GDP'}

[WASHINGTON] A panel of the National Research Council (NRC), part of the US National Academies, has recommended that the US government resume attempts to measure the nation's green gross domestic product, known as 'green GDP'.

Such a measure includes environmental resources in estimates of economic productivity. But the US Congress is unlikely to authorize any work in the near future, having stopped it five years ago.

The Commerce

Department's Bureau of Economic Analysis (BEA) began developing environmental accounting methods in the early 1990s, and in 1994 published its first analysis, of subsoil mineral resources.

That same year, two congressmen from coalproducing states, Harold Rogers (Republican, Kentucky) and Alan Mollohan
(Democrat, West Virginia), led a move to stop work on green GDP until the NRC could assess the methods and objectivity of the department's analysis.

The panel, led by Yale economist William Nordhaus, concluded in its report, released last month, that the BEA's work was sound, and that "developing a set of comprehensive non-market economic accounts is a high priority for the nation".

Rather than fold environmental factors immediately into the core, market-based GDP account, however, it suggests creating a non-market "satellite account". The panel also calls for a "concerted federal effort" to measure changes in the quantity and quality of environmental assets - data that are sorely lacking.

It would cost about $\$ 1.5$ million annually to resume research on green GDP, according to the BEA. But bureau director Steven Landefeld says that, even with the NRC's endorsement, "I'm not sure anything will happen quickly on this". His budget for conventional economic analyses has been lean in recent years, and he estimates that only one person could be assigned to green GDP research part-time if it started up again.

Landefeld says the United States once led in this type of statistical analysis, but has been out of the debate for several years. With the NRC report complete, he says there may be another opportunity for US leadership.

Nordhaus specializes in modelling the economic effects of climate change. The NRC staff behind the green GDP study offered for him to brief the commerce appropriations subcommittee that commissioned the report. So far, though, no one has taken up the offer. Tony Reichhardt more environmental research at the NSF.

The report recommends that the NSF should pursue more research into methods that support environmental assessment and education, and should create environmental research centres at US universities. It should also research better information networks for environmental scientists and support research into environmental technologies, says the report.

But NSF director Rita Colwell stresses that the proposals would stick to basic, rather than applied, research. "The NSF is uniquely placed to lead in basic environmental research," she says.

Research into the genomes of microbes, for example, falls within NSF's remit. But the gathering and processing of environmental data do not. "We wouldn't be monitoring acid rain," says Colwell. "Our sister agencies, such as the Environmental Protection Agency (EPA), do that."

But campaigners for the NIE would like the NSF to do exactly that. They include industry groups that do not trust the EPA's research, and liberal academics who believe the EPA and other agencies do not have enough resources for research.

The Campaign for a National Institute for the Environment (CNIE), which persuaded Congress to ask the NSF to establish an NIE, has drawn support from the US Chamber of Commerce and manyleading scientists. Until she became NSF director last year, Colwell was on the campaign's board of directors.

"The NSB has produced a landmark document," says Richard Benedick, a retired diplomat who is president of the CNIE. "But the real proof of its value will come from how the NSF implements its recommendations." Benedick says that the NSF "was being urged to support both basic and applied research", and it is "regrettable" that it has not backed a new directorate for environmental science.

Ron Pulliam, a professor of ecology at the University of Georgia and former head of the disbanded National Biological Survey at the Department of the Interior, says the report is "very exciting and very promising".

But Pulliam, who is on the CNIE board, suggests that the NSF must look beyond basic research and do some of the environmental assessment work that would support the missions of the rest of the government. "There's a feeling that this is not being done very well, and Congress has been in no mood to give the EPA or the Department of the Interior the money to do it."

Last week's report makes clear that the NSF does not want to do it either. The foundation is proud of its dedication to basic research and fearful of becoming embroiled in controversial policy decisions about environmental regulation.

ColinMacilwain 